8

9

10

\title{
Biology of the world's largest invertebrate, the colossal squid (Mesonychoteuthis hamiltoni): a short review
}

\section{Rui Rosa ${ }^{{ }^{*}}$, Vanessa M. Lopes ${ }^{1,}$ Miguel Guerreiro ${ }^{1,}$ Kathrin Bolstad ${ }^{2}$, José C.} Xavier ${ }^{3,4}$

${ }^{1}$ MARE - Marine Environmental Sciences Centre, Laboratório Marítimo da Guia, Faculdade de Ciências da Universidade de Lisboa, Portugal.

${ }^{2}$ Institute for Applied Ecology New Zealand, Auckland University of Technology, Auckland, New Zealand.

${ }^{3}$ MARE - Marine and Environmental Sciences Centre (MARE), Department of Life Sciences, University of Coimbra, 3004-517 Coimbra, Portugal.

${ }^{4}$ British Antarctic Survey, Natural Environment Research Council, High Cross, Madingley Road, Cambridge CB3 0ET, United Kingdom.

\footnotetext{
* Corresponding author: rrosa@fc.ul.pt
} 
The present study aims to review the current biological knowledge on the largest (heaviest) living invertebrate, the colossal squid Mesonychoteuthis hamiltoni (Robson, 1925). This squid is known to be endemic off the Southern Ocean (SO), with a circumpolar distribution spreading from the Antarctic continent up to the Sub-Antarctic Front. Small juveniles (<40 mm mantle length) are mainly found from the surface to $500 \mathrm{~m}$, and the late juvenile stages are assumed to undergo ontogenetic descent to depths reaching $2000 \mathrm{~m}$. Thus, this giant spends most part of its life in the meso- and bathypelagic realms, where it can reach a total length of 6

Keywords: colossal squid, Mesonychoteuthis hamiltoni, cranchiids, Southern Ocean; meters. The maximum weight recorded so far was $495 \mathrm{~kg}$. Mesonychoteuthis hamiltoni is presently reported from the diets of 17 different predator species, comprising penguins, sea birds, fishes and marine mammals, and feeds on myctophids, Patagonian tootfish, sleeper shark and other squids. Isotopic analysis places the colossal squid as one of the top predators in the SO. Based on phylogenetic inferences, it is assumed that this squid is not capable of high-speed predator-prey interactions, but it is rather an ambush predator. Their eyes, the largest in the planet, seemed to have evolved to detect very large predators (e.g. sperm whales) rather than to detect mates or preys at long distances. On the other hand, and like many other deep-sea animals, it possesses light-emitting organs on the eyes, which may provide ventral camouflage and counter-illumination or some sort of deceptive technique to capture their prey. Although M. hamiltoni is quite abundant in the SO, its life existence remains one of the ocean's great mysteries. This unique invertebrate giant continues to attract considerable attention from media and the public in general, but its study also constitutes a valuable source of insight into the biophysical principles behind body-size evolution. gigantism 


\section{Introduction}

The Southern Ocean consists of a system of deep-sea basins separated by the Scotia Ridge, the Kerguelen plateau (Indian section) and the Macquarie Ridge (South of New Zealand). While the south is limited by the Antarctic continent, the northern part is surrounded by the Antarctic Polar Frontal Zone (APFZ), beginning at the Antarctic convergence / Antarctic Polar Front (APF). The main surface current is the Antarctic Circumpolar Current (ACC), which runs eastwards around the continent (Orsi et al. 1995); Moore et al. (1997); (Moore et al. 1999). These associated fronts create an obstacle to north-south "meridional" circulation, and the discontinuities of temperature and salinity in the APFZ constitute an important barrier in biogeographical interactions (Barnes et al. 2006). Nonetheless, Antarctic life is rich and diverse with high levels of endemism (Arntz et al. 1994; Clarke and Johnston 2003).

Within this unique region, cephalopods are known to play a key role in the marine food webs, because they constitute a vital alternate food source to Antarctic krill Euphausia superba (Collins and Rodhouse 2006). They are important prey, and thus sustain large populations of penguins, procellariform birds, seals and toothed whales (Clarke 1980; Xavier et al. 2002a; Cherel and Duhamel 2004; Cherel et al. 2004; Cherel and Hobson 2005; Cherel and Hobson 2007; Cherel et al. 2007; Xavier et al. 2011). Yet, despite their important ecological role, the basic knowledge of the bio-ecology of Southern Ocean cephalopods is still poorly known (Xavier et al. 1999; Xavier et al. 2014; Alvito et al. 2015; Guerreiro et al. 2015), probably due to an absence of a fishery industry. This may be related to the low number of exploitable species (Xavier et al. 2007), lack of basic knowledge of the species' biology, stocks' 
unpredictability, and the relative inaccessibility of these stocks for exploration and study (Rodhouse et al. 1996; Rodhouse 1998; Collins and Rodhouse 2006).

The majority of the resident Southern Ocean cephalopod fauna comprises endemic species of octopods (cirrate and incirrate), and oegopsid squids, which differ greatly from the taxa found at lower latitudes. There is also a total absence of myopsid squids and cuttlefish, and normally abundant families are rare. Unique Southern Ocean taxa include the squid families Psychroteuthidae and Batoteuthidae, and the genera Psychroteuthis, Kondakovia, Alluroteuthis, Slosarczykovia, Batoteuthis and Mesonychoteuthis. Moreover, several of these cephalopods occupy similar niches to (and compete with) some pelagic top predators, namely sharks and large fishes (Rodhouse and White 1995; Rodhouse et al. 1996; Cherel and Duhamel 2004; Cherel and Hobson 2005). One of these is the most massive living cephalopod - the colossal squid Mesonychoteuthis hamiltoni (Robson 1925)(Fig. 1). This squid is known to be a Southern Ocean endemic, and although it is preyed by many top predators, its basic biology and ecology remain one of the ocean's great mysteries. This review aims to summarize the currently scattered bio-ecological knowledge of the elusive, largest living invertebrate; an overview of the species' taxonomy and detailed treatment of the morphology will be treated in a separate forthcoming publication (Bolstad et al. in prep).

\section{Polar gigantism and some key morphological features of the colossal squid}

For a long time polar scientists have observed that organisms of such areas can reach remarkably large sizes. Polar gigantism is notable tool for understanding the biophysical principles and ecological theories (e.g. temperature-size rule, Bergmann rule, oxygen availability coupled with low metabolic rates hypothesis) 
112 behind body size evolution (Atkinson 1994; Chapelle and Peck 1999; Chapelle and 113 Peck 2004; Vermeij 2016). Although not consensual, some argue that this 114 phenomenon may be linked to the fact that polar giant taxa share common 115 evolutionary histories with deep-sea taxa. In other words, polar gigantism is associated with abyssal gigantism. Yet, it is worth noting that the evolutionary history of (benthic) Southern Ocean fauna is complex and the respective "invasions" worked both ways (i.e. shelf to deep and vice versa) (Brandt et al. 2007; Strugnell et al. 2011). One extreme case of polar gigantism in the Southern Ocean (where other examples of this phenomenon include foraminiferans, sponges, ctenophores, isopods, copepods, amphipods, pycnogonids, pteropods, annelids, echinoderms) is the colossal squid (Fig. 1), which was first described by Robson (1925) from fragments from two squids obtained from sperm whale stomach contents. 
Early stages

Records of egg masses and hatchlings are essentially non-existent. Between 1962 and 1985, only 33 juveniles were reported, all caught using RMT and IKMT nets (Fig. 3). Their mantle length (ML) ranged from 3 to $146 \mathrm{~mm}$, with a clear relationship between juvenile size and depth of capture. In fact, individuals below ML $40 \mathrm{~mm}$ have been mostly found between the surface and $500 \mathrm{~m}$ (Fig. 3) (see more juvenile morphometric information in McSweeny 1970; Fillipova 1972; Filippova 1979; Rodhouse and Clarke 1985; Filippova 1991; Filippova and Pakhomov 1994; Lu and Williams 1994; Anderson and Rodhouse 2002; Filippova life stage) are available.

\section{Age, growth and reproduction}

Besides the characteristic low temperatures, the Southern Ocean is also well known by the drastic annual cycles of productivity. The oscillations from abundance reduced competition and unusually slow growth rates (Lindstedt and Boyce 1985; Arnett and Gotelli 2003; Clarke 2003). Deep-sea and polar environments are also usually linked with low metabolic rates and longer longevity. For instance, Robison et al. (2014) recently reported a female deep-sea benthic octopus Graneledone boreopacifica undertaking an astonishing 53-month brooding period (by far the longest egg-brooding period ever reported for any animal). If brooding comprises about a quarter of this octopod lifespan, this species may be among the longest-lived 
of all cephalopods. Their findings are unparalleled by those from the well-studied shallow-water species and highlights the notion of how little we know about life in marine extreme environments (deep-sea and poles). Within this context, one might imagine that M. hamiltoni may live much longer than their temperate and tropical counterparts, i.e. far longer than 12 to 18 months. The most common method for measuring growth in cephalopods, and consequent age determination, is counting growth increments on statoliths (Lipinski 1986; Rodhouse and Hatfield 1990); however, M. hamiltoni material reported to date has not yet been sufficient to validate the periodicity of statolith-ring formation for this species.

The colossal squid takes longer to mature and reproduce than its more northern relatives, becoming mature at lengths of at least $1 \mathrm{~m}$ and weight above 30 kg (Jereb and Roper 2010). Although in colder waters cephalopods tend to produce a low number of large eggs (Collins and Rodhouse 2006), the colossal squid's potential fecundity has been estimated at a maximum of 4.2 million oocytes (Jereb and Roper 2010), which makes it one of the most fecund cephalopods, especially when compared to other polar cephalopod fauna (Collins and Rodhouse 2006).

\section{Distribution}

Part of the known distribution of the colossal squid is based on the rare encounters with live or recently dead specimens aboard (mainly) toothfish fishing (e.g. Fig. $1 \mathrm{D}$ and E) vessels and the stomach contents of the squid's predators. Mesonychoteuthis hamiltoni has a circumpolar distribution, ranging from the Antarctic continent (excluding respective shelves and Kerguelen Plateau) up to the Sub-Antarctic Front (SAF) (Fig. 4). Based on Xavier et al. (2015b), the highest values of the species' predicted habitat suitability are found: i) between the Weddell Sea 
(Atlantic sector) and the west of the Kerguelen archipelago $\left(\sim 60^{\circ} \mathrm{E}\right)$, and ii) between $180^{\circ} \mathrm{E}$ and $120^{\circ} \mathrm{W}$ in the Ross/Amundsen areas.

\section{Vertical (ontogenetic) movements}

Available information on colossal squid's vertical migrating habits is very scarce. As shown in Figure 3, small juveniles (<40 mm ML) are mainly found from the surface to $500 \mathrm{~m}$. The higher productivity near the surface may confer the young higher chances of feeding between hatching and their probable migration to deeper waters. At late juvenile stages, $M$. hamiltoni is assumed to conduct an ontogenetic descent to depths around 2000m (Lu and Williams 1994). Thus, the colossal squid likely spends the majority of its life (late juvenile, subadult and adult stages) in the meso- and bathypelagic zones of the Southern Ocean. Nonetheless, it is worth noting that female specimens have been captured by fishing vessels at depths shallower waters to spawn, as do other cranchiids.

\section{Predator and prey interactions}

The undigested remains of colossal squid (beaks, tentacular hooks or sucker rings) have been found in a great variety of predators' stomach contents. Presently, M. hamiltoni is known from the diets of 17 different predator species, comprising penguins, sea birds, fishes and marine mammals (Table 1). The larger predators of the colossal squids are the sperm whales (Clarke 1980) and the sleeper sharks (Cherel and Duhamel 2004) (Fig. 5), but in contrast to the former, the latter is a bottom scavenger and ambush predator. One of the more remarkable predator 
211 observations has been made at the Kerguelen Islands, where $66 \%$ of the shark

212 stomachs contained colossal squid remains (Cherel and Duhamel 2004). toothfish (Dissostichus eleginoides) stomach contents (Fig. 5), and in turn, beakshaped bites and scratches from club hooks (matching the colossal squid's) have also been found along the bodies of captured Patagonian toothfish (Remeslo et al. 2015). This may suggest reciprocal predator-prey dynamics. Patagonian toothfish may be able to forage squids larger themselves because they attack dead or moribund colossal squids. Remeslo et al. (2015) also argue that, due to anatomical constraints (namely tooth shape), the toothfish may only scavenge the leftovers of Keyl 2010). intact or undigested stomach contents remain unknown. Moreover, dietary studies 
in cephalopods are difficult to conduct as gut contents are usually in an advanced

237 state of digestion, making identification of prey items difficult to impossible.

Cephalopods also macerate their preys finely before ingestion, using their beaks and radula. It has been suggested that $M$. hamiltoni feeds on myctophids, Patagonian toothfish, sleeper sharks and other squids (Jereb and Roper 2010; Roberts et al. 2011). Based on phylogenetic (metabolic) inferences and polar gigantism constraints, Rosa and Seibel (2010) argued that the colossal squid is probably not a predator capable of high-speed predator-prey interactions (see also section 3.5). Therefore, the very large but immobilized (or weakened) toothfish specimens captured by longline would present easy, opportunistic prey for M. hamiltoni hamiltoni is definitely one of the top predators in the Southern Ocean (Fig. 6).

Vision

Giant (Architeuthis dux) and colossal squids possess the largest eyes in the World oceans (Fig. 7), and on the planet (Walls 1942; Land and Nilsson 2002). Since both of these squid species are pelagic organisms that share (or compete for) similar ecological niches with other (vertebrate) top predators, the tremendous differences in eye size may indicate a different purpose for the use of eyes. Nilsson et al. (2012) 
suggested that the very large eyes may have conferred an evolutionary advantage in increased ability to detect large predators (especially sperm whales), rather for utility in detecting mates or prey at long distances. These authors modelled large squids' visual range and proposed that the giant eyes enable them to detect sperm whales as they trigger plankton bioluminescence while swimming through the water column. In other words, as whales conduct hunting dives, they attain considerable speed and agitate the deep waters where a great variety of bioluminescent organisms thrive. The colossal squid's eyes, due to their large retina, are able to detect such small sources of light from a distance, although they may not necessarily register the predators before being detected themselves by the whale's sonar (the range of which can exceed $120 \mathrm{~m}$ ). The squid may, however, be visually warned in sufficient time to attempt an escape (Nilsson et al. 2012). Nonetheless, it is worth noting that Schmitz et al. (2013) also argued that M. hamiltoni 's eyes are a phylogenetically conserved trait. colossal squid "is not a voracious predator capable of high-speed predator-prey

\section{Metabolism}

Rosa and Seibel (2010) calculated the metabolic rates and energy requirements of the colossal squid through a depth-temperature gradient representative of the Southern Ocean (Fig. 8). This phylogenetic inference was conducted based on other deep-sea cranchiid data and followed the expected allometric relationship between body size and metabolism (Seibel 2007; Seibel and Drazen 2007; Rosa et al. 2009). Based on their findings, the authors argued that the interactions. It is, rather, an ambush or sit-and-float predator that uses the hooks on 
its arms and tentacles to ensnare prey that unwittingly approach". The colossal squid was long thought to be an intrepid predator, due to the "kraken"-related myths and stories associated with its large size, but after this study, it has been postulated that the colossal squid perhaps does not deserve such a reputation. The question that we now raise is: does an organism need to be an active pursuit predator to be fearsome? For instance, white sharks, leopards, crocodiles, large monkfish and pythons are all ambush predators (many with low energy demands), and it is their capability to hide and strike without warning that makes them inherently aggressive.

\section{Bioluminescence}

Like the great majority of deep sea inhabitants, M. hamiltoni possesses light-emitting organs (photophores), in the form of two elongate structures on the ventral surface of each eye (Fig. 9) (Herring et al. 2002). The smaller is located anteriorly while the larger is crescent-shaped and located posteriorly around the outside rim of the iris (Voss 1980). M. hamiltoni photocytes contain crystalloids whose profiles appear as rectangular blocks or elongate needles, and the reflector platelets are unusual, being associated with a microtubular array that confers their edges a comb-like arrangement in which the illuminated surface of each light-emitting organ extends 
310 photophores of $M$. hamiltoni may serve as ventral camouflage and counter-

311 illumination, to blend in with downwelling light when seen from below (Young 1975; Young 1977; Young et al. 1980). Yet, this seems to be not useful in large squid

313 individuals since their main predators are not visually-orientated hunters.

314 Photophores may also be used as a deceptive technique - when illuminated, other

315 organisms may disregard the colossal squid as a threat, allowing it to approach its

316 prey. Alternatively, the photophores may be used as "flashlights" to more accurately

317 predict the distance needed to stretch its hooked tentacles and successfully capture unwitting prey.

\section{Future directions}

321 Further efforts should be made to understand more about the life of this giant. It has been assumed that M. hamiltoni is quite abundant in the Southern Ocean (biomass of around 90 million tonnes) and there have been some reports on its interest to fisheries (Jereb and Roper 2010). Every sample, fragment or sighting has proved to be a highly valuable source of information and helped scientists to unveil more and more about M. hamiltoni. Baited cameras and remotely operated vehicles could be deployed in the search of live footage, as has happened recently for other deep sea "giant" squids, e.g. Architeuthis dux (Kubodera and Mori 2005) and Taningia danae (Kubodera et al. 2006). M. hamiltoni and other Antarctic organisms has been widely used for education and outreach activities worldwide (Xavier et al. 2015a). Besides the fact that these unique invertebrate giants continue to attract considerable attention from media and the public in general, it is important to highlight, in the words of Vermeij (2016), that: "Gigantism is (...) a functionally distinct and ecologically important condition that is both enabled by resources and compelled by 
natural selection. The distribution of maximum size in time and space can therefore

inform our understanding of major patterns in the history of life."

\section{Acknowledgements}

This study benefited from the strategic program of MARE, financed by FCT (MARE -

UID/MAR/04292/2013). JX is supported by the Investigator FCT program

(IF/00616/2013) and by the Foundation for Science and Technology (Portugal) and

is associated to SCAR AnT-ERA, SCAR EGBAMM, ICED, BAS-CEPH programs. RR is

supported by the Investigator FCT program (IF/01373/2013).

\section{References}

Alvito PM, Rosa R, Phillips RA, Cherel Y, Ceia F, Guerreiro M, Seco J, Baeta A, Vieira RP, Xavier JC (2015) Cephalopods in the diet of nonbreeding black-browed and grey-headed albatrosses from South Georgia. Polar Biology 38:631-641

Anderson CIH, Rodhouse PG (2002) Distribution of juvenile squid in the Scotia Sea in relation to regional oceanography. Bulletin of Marine Science 71:97-108

Arata J, Robertson G, Valencia J, Xavier J, Eacute C, Moreno CA (2004) Diet of grey-headed albatrosses at the Diego Ramírez Islands, Chile: ecological implications. Antarctic Science 16:263-275 doi doi:10.1017/S095410200400207X

Arnett AE, Gotelli NJ (2003) Bergmann's rule in larval ant lions: testing the starvation resistance hypothesis. Ecol Entomol 6:645-650

Arntz WE, Brey T, A. GV (1994) Antarctic zoobenthos. Oceanogr Mar Biol Ann Rev 32:241-304

Atkinson D (1994) Temperature and organism size - a biological law for ectotherms? . Adv Ecol Res 25:1-58

Barnes DKA, Hodgson DA, Convey P, Allen CS, Clarke A (2006) Incursion and excursion of Antarctic biota: past, present and future Global Ecology and Biogeography 15:121-142

Bolstad KS, O'Shea S (2004) Gut contents of a giant squid Architeuthis dux (Cephalopoda: Oegopsida) from New Zealand waters. New Zealand Journal of Zoology 31:15-21

Brandt A, Gooday AJ, Brandão SN, Brix S, Brökeland W, Cedhagen T, Choudhury M, Cornelius N, Danis B, De Mesel I (2007) First insights into the biodiversity and biogeography of the Southern Ocean deep sea. Nature 447:307-311

Chapelle G, Peck LS (1999) Polar gigantism dictated by oxygen availability. Nature 399:114-115

Chapelle G, Peck LS (2004) Amphipod crustacean size spectra: new insights in the relationship between size and oxygen. Oikos 106:167-175

Cherel Y, Duhamel G (2004) Antarctic jaws: cephalopod prey of sharks in Kerguelen waters. Deep-Sea Research Part I-Oceanographic Research Papers 51:17-31 doi 10.1016/j.dsr.2003.09.009 
Cherel Y, Duhamel G, Gasco N (2004) Cephalopod fauna of subantarctic islands: new information from predators. Marine Ecology Progress Series 266:143-156 doi $10.3354 /$ meps 266143

Cherel Y, Hobson KA (2005) Stable isotopes, beaks and predators: a new tool to study the trophic ecology of cephalopods, including giant and colossal squids. Proceedings of Royal Society B 272:1601-1607

Cherel Y, Hobson KA (2007) Geographical variation in carbon stable isotope signatures of marine predators: a tool to investigate their foraging areas in the Southern Ocean. Marine Ecology Progress Series 329:281-287 doi 10.3354/meps329281

Cherel Y, Hobson KA, Guinet C, Vanpe C (2007) Stable isotopes document seasonal changes in trophic niches and winter foraging individual specialization in diving predators from the Southern Ocean. Journal of Animal Ecology 76:826-836 doi 10.1111/j.13652656.2007.01238.x

Cherel Y, Klages N (1998) A review of the food of albatrosses. In: Robertson G, Gales R (eds) Albatross Biology and Conservation. Surrey Beatty \& Sons, Chipping Norton, Australia, pp 113-136

Clarke A (2003) Evolution, adaptation, and diversity: global ecology in an Antarctic context. In: Huiskes AHL, Gieskes WWC, Rozema J, Schorno RML, van der Vies SM, Wolff WJ (eds) Antarctic Biology in a Global Context. Int. Biol. Symp. Backhuys Publishers, Leiden, pp 3-17

Clarke A, Johnston NM (2003) Antarctic marine benthic diversity. Oceanogr Mar Biol Ann Rev 41:47-114

Clarke MR (1980) Cephalopoda in the diet of sperm whales of the southern hemisphere and their bearing on sperm whale biology. Discovery Reports 37:324

Clarke MR, Goodall N (1994) Cephalopods in the diets of three Odontoceti cetacean species stranded at Tierra del Fuego, Globicephala melaena (Traill, 1809), Hyperoodon planifrons Flower, 1882 and Cephalorhynchus commersonii (Lacepede, 1804). Antarctic Science 6:149-154

Clarke MR, MacLeod N (1982) Cephalopod remains from the stomachs of sperm whales caught in the Tasman sea. Memoirs of the National Museum Victoria 43:25-42

Clarke MR, MacLeod N, Paliza O (1976) Cephalopod remains from the stomachs of Sperm whales caught off Peru and Chile. Journal of Zoology 180:477-493

Clarke MR, Prince PA (1981) Cephalopod remains in regurgitations of black-browed and greyheaded albatrosses at South Georgia. British Antarctic Survey Bulletin 54:1-8

Collins MA, Rodhouse PG (2006) Southern Ocean cephalopods. Advances in Marine Biology 50:191-265

Cooper J, Brown CR (1990) Ornithological research at the sub-Antarctic Prince Edward Islands: a review of achievements. South Africa Trans Nav Antarkt 20:40-57

Cooper J, Henley S, Klages N (1992) The diet of the wandering albatross Diomedea exulans at subantarctic Marion Island. Polar Biology 12:477-484

Croxall JP, Prince PA (1994) Dead or alive, night or day - how do albatrosses catch squid. Antarctic Science 6:155-162

Filippova J (1991) Morpho-ecological aspects of the study of Antarctic squids. Bull Mar Sci 49:662

Filippova JA (2002) Review of Soviet/Russian studies on squids in the Antarctic Ocean. Bulletin of Marine Science 71:255-267

Filippova JA, Pakhomov EA (1994) Young squid in the plankton of Prydz Bay, Antarctica. Antarctic Science 6:171-173 doi doi:10.1017/S095410209400026X

Filippova JAY, V. L. (1979) Specific composition and distribution of cephalopod molluscs in meso- and bathypelagic Antarctic waters. Antarktika Doklady Komissi:175-187

Fillipova JA (1972) New data on the squids (Cephalopoda: Oegopsida) from the Scotia Sea (Antarctic). Malacologia 11:391-406 
Fiscus CH, Rice DW, Wolman AA (1989) Cephalopods from the stomachs of sperm whales taken off California. NOAA Technical Report NMFS 83:1-12

Fonseca Vd, Petry M (2007) Evidence of food items used by Fulmarus glacialoides (Smith 1840) (Procellariiformes: Procellariidae) in Southern Brazil. Polar Biology 30:317-320 doi 10.1007/s00300-006-0185-7

Green K, Kerry KR, Disney T, Clarke MR (1998) Dietary studies of light-mantled sooty albatrosses Phoebetria palpebrata from Macquarie and Heard Islands. Marine Ornithology 26:19-26

Guerreiro M, Phillips RA, Cherel Y, Ceia FR, Alvito P, Rosa R, Xavier JC (2015) Habitat and trophic ecology of Southern Ocean cephalopods from stable isotope analyses. Marine Ecology Progress Series 530:119-134 doi 10.3354/meps11266

Herring PJ, Dilly PN, Cope C (2002) The photophores of the squid family Cranchiidae (Cephalopoda: Oegopsida). Journal of Zoology 258:73-90

Ibáñez CM, Keyl F (2010) Cannibalism in cephalopods. Rev Fish Biol Fish 20:123-136

Imber MJ (1992) Cephalopods eaten by wandering albatrosses Diomedea exulans L. breeding at six circumpolar localities. Journal of the Royal Society of New Zealand 22:243-263

Imber MJ, Berruti A (1981) Proccellariiform seabirds as squid predators. In: Cooper J (ed) Proceedings of the Symposium on Birds of the Sea and Shore. African Seabird Group, Cape Town, pp 43-61

Jereb P, Roper CFE (2010) Cephalopods of the world. An annotated and illustrated catalogue of cephalopod species known to date. Myopsidae and Oegopsidae. FAO, Rome

Jereb P, Roper CFE, Norman MD, Finn JK (2014) Cephalopods of the world. An annotated and illustrated catalogue of cephalopod species known to date. Volume 3. Octopods and Vampire Squids. . FAO, Rome

Kent S, Seddon J, Roberston G, Wienecke BC (1998) Diet of Adélie penguins Pygoscelis adeliae at Shirley Island, East Antarctica, January 1992. Marine Ornithology 26:7-10

Klumov SK, Yukhov VL (1975) Mesonychoteuthis hamiltoni Robson, 1925 (Cephalopoda: Oegopsida). Antarktika Doklady Komission 14:159-189

Korabelnikov L (1959) The diet of sperm whales in the Antarctic seas. Priroda 3:103-104

Kubodera T, Koyama Y, Mori K (2006) Observations of wild hunting behaviour and bioluminescence of a large deep-sea, eight-armed squid, Taningia danae. Proceedings of Royal Society B doi:10.1098/rspb.2006.0236

Kubodera T, Mori K (2005) First-ever observations of a live giant squid in the wild. Proceedings of Royal Society $B$ in press

Land MF, Nilsson D-E (2002) Animal Eyes. Oxford University Press, Oxford

Lindstedt SL, Boyce MS (1985) Seasonality, fasting endurance, and body size in mammals. Am Nat 125:873-878

Lipinski MR (1986) Methods for the validation of squid age from statoliths. Journal of the Marine Biological Association of the United Kingdom 66:505-526 doi doi:10.1017/S0025315400043095

Lipinski MR, Jackson S (1989) Surface-feeding on cephalopods by procellariiform seabirds in the southern Benguela region, South Africa. Journal of Zoology 218:549-563

Lu CC, Williams R (1994) Contribution to the biology of squid in the Prydz Bay region, Antarctica. Antarctic Science 6:223-229 doi doi:10.1017/S0954102094000349

McClain CR, Balk MA, Benfield MC, Branch TA, Chen C, Cosgrove J, Dove AD, Gaskins LC, Helm RR, Hochberg FG (2015) Sizing ocean giants: patterns of intraspecific size variation in marine megafauna. PeerJ 3:e715

McSweeny ES (1970) Description of the juvenile form of the Antarctic squid Mesonychoteuthis hamiltoni Robson. Malacologia:323-332

Moore JK, Abbott MR, Richman JG (1997) Variability in the location of the Antarctic Polar Front (90 degrees-20 degrees $W$ ) from satellite sea surface temperature data. Journal of Geophysical Research-Oceans 102:27825-27833 doi 10.1029/97jc01705 
Moore JK, Abbott MR, Richman JG (1999) Location and dynamics of the Antarctic Polar Front from satellite sea surface temperature data. Journal of Geophysical Research-Oceans 104:3059-3073

Nilsson DE, Warrant EJ, Johnsen S, Hanlon R, Shashar N (2012) A unique advantage for giant eyes in giant squid. Current biology : CB 22:683-688 doi 10.1016/j.cub.2012.02.031

Orsi AH, Whitworth T, Nowlin WD (1995) On the meridional extent and fronts of the Antarctic Circumpolar Current Deep-Sea Research Part I-Oceanographic Research Papers 42:641-673 doi 10.1016/0967-0637(95)00021-w

Petrov AF, Tatarnikov VA (2011) Results of investigation of the diet of antarctic toothfish Dissostichus mawsoni (Nototheniidae) in the Lazarev Sea. Journal of Ichthyology 51:131-135 doi 10.1134/S0032945210051017

Remeslo AV, Yakushev MR, Laptikhovsky V (2015) Alien vs. Predator: interactions between the colossal squid (Mesonychoteuthis hamiltoni) and the Antarctic toothfish (Dissostichus mawsoni). Journal of Natural History 49:2483-2491 doi 10.1080/00222933.2015.1040477

Ridoux V (1994) The diets and dietary segregation of seabirds at the Subantarctic Crozet Islands. Marine Ornithology 22:1-192

Roberts J, Xavier JC, Agnew DJ (2011) The diet of toothfish species Dissostichus eleginoides and Dissostichus mawsoni with overlapping distributions. J Fish Biol 79:138-154 doi 10.1111/j.1095-8649.2011.03005.x

Robertson G, Williams R, Green K, Robertson L (1994) Diet composition of emperor penguin chicks Aptenodytes forsteri at two Mawson Coast colonies, Antarctica. Ibis 136:19-31

Robison BH, Seibel BA, Drazen JC (2014) Deep-Sea Octopus (Graneledone boreopacifica) conducts the longest-known egg-brooding period of any animal. Plos One 9:e103437

Robson GC (1925) On Mesonychoteuthis, a new genus of oegopsid Cephalopoda. Annals and Magazine of Natural History:272-277

Rodhouse P, Hatfield E (1990) Age determination in squid using statolith growth increments. Fisheries Research 8:323-334

Rodhouse PG (1998) Large and meso-scale distribution of the ommastrephid squid Martialia hyadesi in the Southern Ocean: a synthesis of information relevant to fishery forecasting and management. Korean Journal of Polar Research 8:145-154

Rodhouse PG, Arnbom T, Fedak MA, Yeatman J, Murray AWA (1992) Cephalopod prey of the southern elephant seal, Mirounga leonina L. Canadian Journal of Zoology 70:10071015

Rodhouse PG, Clarke MR (1985) Growth and distribution of young Mesonychoteuthis hamiltoni Robson (Mollusca: Cephalopoda): An Antarctic squid. Vie et Milieu 35:223-230

Rodhouse PG, Clarke MR, Murray AWA (1987) Cephalopod prey of the wandering albatross Diomedea exulans. Marine Biology 96:1-10

Rodhouse PG, Prince PA, Trathan PN, Hatfield EMC, Watkins JL, Bone DG, Murphy EJ, White MG (1996) Cephalopods and mesoscale oceanography at the Antarctic Polar Front: Satellite tracked predators locate pelagic trophic interactions. Marine Ecology Progress Series 136:37-50 doi 10.3354/meps136037

Rodhouse PG, White MG (1995) Cephalopods occupy the ecological niche of epipelagic fish in the Antactic Polar Frontal zone. Biological Bulletin 189:77-80 doi 10.2307/1542457

Rosa R, Seibel BA (2010) Slow pace of life of the Antarctic colossal squid. Journal of the Marine Biological Association of the United Kingdom 90:1375-1378 doi $10.1017 / \mathrm{s} 0025315409991494$

Rosa R, Trueblood L, Seibel BA (2009) Ecophysiological influence on scaling of aerobic and anaerobic metabolism of pelagic gonatid squids. Physiological and Biochemical Zoology $82: 419-429$ 
Schmitz L, Motani R, Oufiero C, Martin C, McGee M, Gamarra A, Lee J, Wainwright P (2013) Allometry indicates giant eyes of giant squid are not exceptional. BMC Evolutionary Biology 13:45

Seibel BA (2007) On the depth and scale of metabolic rate variation: scaling of oxygen consumption rates and enzymatic activity in the Class Cephalopoda (Mollusca). Journal of Experimental Biology 210:1-11

Seibel BA, Drazen JC (2007) The rate of metabolism in marine animals: environmental constraints, ecological demands and energetic opportunities. Philosophical Transactions of the Royal Society B 362:2061-2078

Seibel BA, Thuesen EV, Childress JJ (2000) Light-limitation on predator-prey interactions: consequences for metabolism and locomotion of deep-sea cephalopods. Biological Bulletin 198:284-298

Stowasser G, Atkinson A, McGill RAR, Phillips RA, Collins MA, Pond DW (2012) Food web dynamics in the Scotia Sea in summer: A stable isotope study. Deep Sea Research Part II: Topical Studies in Oceanography 59-60:208-221 doi 10.1016/j.dsr2.2011.08.004

Strugnell JM, Cherel Y, Cooke IR, Gleadall IG, Hochberg FG, Ibáñez CM, Jorgensen E, Laptikhovsky VV, Linse K, Norman Mea (2011) The Southern Ocean: Source and sink? Deep Sea Res Part II 58:196-204

Vermeij GJ (2016) Gigantism and Its Implications for the History of Life. Plos One 11:e0146092 doi 10.1371/journal.pone.0146092

Voss N, Stephen SJ, Dong Z (1992) Family Cranchiidae. Smithsonian Contributions to Zoology 513:187-210

Voss NA (1980) A generic revision of the Cranchiidae (Cephalopoda, Oegopsida). Bulletin of Marine Science 30:365-412

Walls GL (1942) The vertebrate eye and its adaptive radiation. Bloomfield Hills, Cranbrook

Xavier JC, Allcock L, Cherel Y, Hoving H-J, Lipinski M, Gomes-Pereira JN, Piatkowski U, Pierce G, Rodhouse PG, Rosa R, Liz Shea L, Strugnell J, Vidal E, Villanueva R, Ziegler A (2015a) The future challenges in cephalopod research for the next decade. Journal of the Marine Biological Association of the United Kingdom 95:999-1015

Xavier JC, Cherel Y (2009) Cephalopod beak guide for the Southern Ocean. British Antarctic Survey, Cambridge, UK

Xavier JC, Croxall JP (2007) Predator-prey interactions: why do larger albatrosses eat bigger squid? Journal of Zoology 271:408-417 doi 10.1111/j.1469-7998.2006.00224.x

Xavier JC, Croxall JP, Reid K (2003a) Inter-annual variation in the diet of two albatross species breeding at South Georgia: implications for breeding performance. Ibis 145:593-610

Xavier JC, Croxall JP, Trathan PN, Rodhouse PG (2003b) Inter-annual variation in the cephalopod component of the diet of wandering albatrosses Diomedea exulans breeding at Bird Island, South Georgia. Marine Biology 142:611-622

Xavier JC, Phillips RA, Cherel Y (2011) Cephalopods in marine predator diet assessments: why identifying upper and lower beaks is important. ICES Journal of Marine Science 68:1857-1864 doi 10.1093/icesjms/fsr103

Xavier JC, Raymond B, Jones DC, Griffiths H (2015b) Biogeography of cephalopods in the Southern Ocean using habitat suitability prediction models. Ecosystems 19:220-247 doi 10.1007/s10021-015-9926-1

Xavier JC, Rodhouse PG, Purves MG, Daw TM, Arata J, Pilling GM (2002a) Distribution of cephalopods recorded in the diet of the Patagonian toothfish (Dissostichus eleginoides) around South Georgia. Polar Biology 25:323-330

Xavier JC, Rodhouse PG, Purves MG, Daw TM, Arata J, Pilling GM (2002b) Distribution of cephalopods recorded in the diet of the Patagonian toothfish (Dissostichus eleginoides) around South Georgia. Polar Biology 25:323-330 doi 10.1007/s00300-0010343-x 
Xavier JC, Rodhouse PG, Trathan PN, Wood AG (1999) A Geographical Information System (GIS) atlas of cephalopod distribution in the southern ocean. Antarctic Science 11:61-62

Xavier JC, Walker K, Elliott G, Cherel Y, Thompson D (2014) Cephalopod fauna of South Pacific waters: new information from breeding New Zealand wandering albatrosses. Marine Ecology Progress Series 513:131-142 doi 10.3354/meps10957

Xavier JC, Wood AG, Rodhouse PG, Croxall JP (2007) Interannual variations in cephalopod consumption by albatrosses at South Georgia: implications for future commercial exploitation of cephalopods. Marine and Freshwater Research 58:1136-1143 doi 10.1071/mf06237

Young RE (1975) Transitory eye shapes and the vertical distribution of two midwater squids. Pacific Science 29:243-255

Young RE (1977) Ventral bioluminescence countershading in midwater cephalopods. In: Nixon $\mathrm{M}$, Messenger J (eds) Biology of cephalopods Symposia of the Zoological Society of London №38 Academic Press, London, pp 161-190

Young RE, Kampa EM, Maynard SD, Mencher FM, Roper CFE (1980) Counterillumination and the upper depth limits of midwater animals. Deep-Sea Research Part A 27:671-691

Yukhov VL (2012) Antarctic deep-water squid (ADS) Mesonychoteuthis hamiltoni, Robson, 1925. Distribution and borders of the geographic range. Main results of complex research in the Azov and Black Seas Basin and the World Ocean. Kerch: YugNIRO 50:241-248. Russian 


\begin{tabular}{|c|c|c|c|}
\hline $\begin{array}{l}\text { Predator groups and } \\
\text { common names }\end{array}$ & Species & Geographical location & Reference \\
\hline \multicolumn{4}{|l|}{ Penguins } \\
\hline King pengin & Aptenodytes patagonicus & Crozet & Ridoux (1994) \\
\hline Adélie penguin & Pygoscelis adeliae & Shirley Islands, East Antarctica & Kent et al. (1998) \\
\hline Emperor penguin & Aptenodytes forsteri & Mawson & Robertson et al. (1994) \\
\hline \multicolumn{4}{|l|}{ Seabirds } \\
\hline Southern fulmar & Fulmarus glacialoides & South Brazil & Fonseca and Petry (2007) \\
\hline Wandering albatross & Diomedia exulans & $\begin{array}{l}\text { Marion, Macquarie, Prince Edward, } \\
\text { Crozet Is., South Georgia, Antipodes }\end{array}$ & $\begin{array}{l}\text { (Clarke and Prince 1981; Imber and Berruti 1981; } \\
\text { Rodhouse et al. 1987; Cooper and Brown 1990); Cooper et } \\
\text { al. (1992); (Imber 1992; Ridoux 1994; Cherel and Klages } \\
\text { 1998; Xavier et al. 2003a; Xavier et al. 2003b) }\end{array}$ \\
\hline Black-browed albatross & Thalassarche melanophrys & South Georgia & Xavier et al. (2003a) \\
\hline Grey-headed albatross & Thalassarche chrysostoma & Diego Ramirez; South Georgia, & $\begin{array}{l}\text { (Cherel and Klages 1998; Xavier et al. 2003a; Arata et al. } \\
\text { 2004; Alvito et al. 2015) }\end{array}$ \\
\hline Light-mantled albatross & Phoebetria palpebrata & $\begin{array}{l}\text { Crozet, Prince Edward Island, } \\
\text { Marion Island; Macquarie and } \\
\text { Heard islands }\end{array}$ & $\begin{array}{l}\text { (Imber and Berruti 1981; Cooper and Brown 1990; Ridoux } \\
\text { 1994; Cherel and Klages 1998; Green et al. 1998) }\end{array}$ \\
\hline White-chinned petrel & Procellaria aequinoctialis & $\begin{array}{l}\text { South Africa (Benguela Current); } \\
\text { Marion Is. }\end{array}$ & Lipinski and Jackson (1989) \\
\hline Sooty albatross & Phoebetria fusca & Marion and Crozet Islands & $\begin{array}{l}\text { (Imber and Berruti 1981; Cooper and Brown 1990; Ridoux } \\
\text { 1994; Cherel and Klages 1998) }\end{array}$ \\
\hline \multicolumn{4}{|l|}{ Fishes } \\
\hline Sleeper shark & Somniosus cf. Microcephalus & Kerguelen & Cherel and Duhamel (2004) \\
\hline Patagonian toothfish & Dissostichus eleginoides & Crozet, South Georgia & (Xavier et al. 2002b; Cherel et al. 2004) \\
\hline Antarctic toothfish & Dissostichus mawsoni & $\begin{array}{l}\text { Lazarev Sea, South Sandwich } \\
\text { Islands }\end{array}$ & (Petrov and Tatarnikov 2011; Roberts et al. 2011) \\
\hline
\end{tabular}


Mirounga leonina

Physeter macrocephalus

604

South Georgia

Antarctica, South America, South Georgia, Peru and Chile, Tasman sea

South America

South America
Rodhouse et al. (1992)

(Korabelnikov 1959; Clarke et al. 1976; Clarke 1980; Clarke and MacLeod 1982; Fiscus et al. 1989)

Clarke and Goodall (1994)

Clarke and Goodall (1994) 
Figure captions

622

Figure 1 - Length and weight (logarithmic scale) of the marine invertebrate (grey bars) and vertebrate giants (blue bars), with a special emphasis on the cephalopods: giant octopus (Enteroctopus dofleini), giant squid (Architeuthis $d u x$ ) and colossal squid Mesonychoteuthis hamiltoni (red bar). Cephalopod data from Jereb and Roper (2010) and Jereb et al. (2014). Other groups' data from McClain et al. (2015) and references within.

Figure 2 - Morphological dissimilarities between the colossal squid (Mesonychoteuthis hamiltoni) and other cranchiid species. Panels A, B and C show the translucent bodies of deep-sea glass squids Teuthowenia pellucida and Taonius borealis (copyright: MBARI). Panels D and E show the much denser musculature of the colossal squid (photo credits: AP San Aspring crew of Sanford Company). Panels F, G, H highlight the beak size, the presence of rotating hooks on its tentacles, and eye lens size of the colossal squid (copyright: Museum of New Zealand Te Papa Tongarewa).

Figure 3 - Number of colossal squid (Mesonychoteuthis hamiltoni) specimens caught in nets (RMT- Rectangular midwater trawl, IKMT - Isaacs-Kidd Midwater trawl, and other trawls) within the Southern Ocean, and the relationship between juvenile mantle length $(\mathrm{mm})$ and depth of capture.

Figure 4 - Map of the locations of all known colossal squid (Mesonychoteuthis hamiltoni) occurrences. "Squid" symbol represents locations obtained from nets and the other symbols represent predator diet studies (penguins, seabirds, fish and sharks) [modified from Xavier et al. (2015b)].

Figure 5 - Predicted mantle length $(\mathrm{mm})$ of the colossal squid (Mesonychoteuthis hamiltoni) found in the stomachs remains (namely beaks) of its predators. The estimated values are based on beaks' morphometrics (namely lower rostral length) and the respective allometric equation (see Xavier and Cherel 2009). 
659

660

661

662

663

664

665

666

667

668

669

670

Abbreviations: A.p. - Aptenodytes patagonicus; Dio.e. - Diomedia exulans; Diss.e. - Dissostichus eleginoides; G.m. - Globicephala melaena; H.p. Hyperoodon planifrons; P.f. - Phoebetria fusca; P.m. - Physeter macrocephalus; P.p. - Phoebetria palpebrata; S.m. - Somniosus cf Microcephalus; T.c. Thalassarche chrysostoma. The references for beak data (for the different predator species) can be found in Table 1 .

Figure $6-\delta^{15} \mathrm{~N}$ values (trophic level) of squid (grey bars) and other marine animals collected in the Southern Ocean. * - corrected (beak) values. Data from Guerreiro et al. (2015), Stowasser et al. (2012) and references within.

Figure 7 - Biggest eyes (mm) in the ocean. Data from Walls (1942), Land and Nilsson (2002) and Nilsson et al. (2012).

Figure 8 - Metabolic ecology of the colossal squid (Mesonychoteuthis hamiltoni) in the Southern Ocean. Panel A: Effect of size in the routine mass-specific metabolic rate of deep-sea cranchiid squids (blue circles, from a $0.017 \mathrm{~g}$ Liocranchia valdiviae to $500 \mathrm{~kg}$ M. hamiltoni) and of other cephalopod counterparts, including loliginids (green line), coastal ommastrephids (dark red line), coastal benthic octopods (red line), pelagic gelatinous octopods (light blue line) and vampire squid (purple line). Value of $20 \mathrm{~kg}$ giant squid (Architeuthis spp.; solid triangle) was based on the activity of citrate synthase measured in mantle muscle (Seibel et al. 2000). Rates were standardized to $1.5^{\circ} \mathrm{C}$ assuming a Q10 of 2. Data from Rosa and Seibel (2010) and Seibel (2007). Panels B and C represent depth-related changes in temperature in the circum-Antarctic Southern Ocean. Dashed lines represent sub-Antarctic areas (50.58S0.58E; 50.58S90.58E; 50.58S179.58W; 50.58S90.58W) and solid lines represent Antarctic areas (60.58S0.58E; 60.58S90.58E; 60.58S179.58W; 60.58S90.58W); (B) projected energy consumption (kcal day ${ }^{-1}$; based on 4.7 $\mathrm{kcal} / \mathrm{l}_{2}$ ) as a function of depth (temperature dependence of 2) in the circumAntarctic Southern Ocean region. Thick solid line represents the mean values obtained from the different temperature profiles. Thin dashed line represents 
the 95\% confidence interval for the means (modified from Rosa and Seibel 2010).

Figure 9 - Photophores of the colossal squid (Mesonychoteuthis hamiltoni). Panel A shows the light organ at the rear of the eyeball, while Panel B shows the eyelid being pulled back to reveal part of the light organ (at the rear of the eyeball) (copyright: Museum of New Zealand Te Papa Tongarewa). Panels C and D show the colossal squid's photocytes containing paracrystalline aggregates (needle-like or rectangle structures) and Panel E shows the reflector platelets with edges of comb-like appearance (modified from Herring et al. 2002; copyright: John Wiley \& Sons, Inc.). 